\title{
Analisis Kemampuan Representasi Matematis Siswa SMP pada Materi Statistika
}

\author{
Endah Silviani', Dian Mardiani2 ${ }^{*}$, Deddy Sofyan ${ }^{3}$ \\ Program Studi Pendidikan Matematika, Institut Pendidikan Indonesia \\ Jalan Pahlawan No 32 Sukagalih, Garut, Jawa Barat, Indonesia \\ 1endahsilviani1904@gmail.com; ${ }^{2}$ dianmardiani5858@gmail.com; \\ 3deddysofyan1968@gmail.com
}

Artikel diterima: 05-03-2021, direvisi: 29-09-2021, diterbitkan: 30-09-2021

\begin{abstract}
Abstrak
Kemampuan representasi matematis sangat penting dalam pembelajaran matematika, akan tetapi dalam kenyataannya siswa cenderung meniru langkah guru dalam menyelesaikan masalah. Tujuan dari penelitian ini adalah untuk mendeskripsikan kemampuan representasi verbal, representasi gambar, dan representasi simbol, serta pemahaman dari siswa SMP pada materi statistika. Penelitian ini menggunakan metode penelitian deskriptif. Kesimpulan yang diperoleh dari penelitian ini adalah pada indikator kemampuan representasi verbal dan indikator kemampuan representasi gambar atau visual ketiga subjek yang diteliti sudah cukup menguasai. Pada indikator kemampuan representasi simbol hanya dua subjek yang sudah menguasai, sedangkan satu subjek lainya kurang memahami representasi simbol. Pada pemahaman mengenai materi statistika, rata-rata dari ketiga subjek yang diteliti sudah cukup menguasai materi statistika. Saran penulis bagi guru adalah upayakan guru berusaha memberikan metode dalam penyampaian materi yang membuat siswa bersemangat misalnya memberikan materi melalui video supaya siswa tidak merasa bosan.
\end{abstract}

Kata Kunci: Kemampuan Representasi, Statistika.

\section{Analysis of Mathematic Representation Ability of Junior Highschool Students in Statistics Materials}

\begin{abstract}
The ability of mathematical representation is very important in learning mathematics, but in reality, students tend to imitate the teacher's steps in solving problems. The purpose of this study was to describe the ability of verbal representation, image representation, and representation of symbols, as well as an understanding of junior high school students on statistical material. This study uses descriptive research methods. The conclusions obtained from this study are the indicators of verbal representation capabilities and indicators of the capabilities of the representation of the image or visual three subjects studied have been quite mastered. In indicators, the ability of the symbolic representation is only two subjects that have mastered, while the other subjects do not understand the representation of the symbol. In an understanding of statistical material, the average of the three subjects studied has sufficiently mastered statistical material. The author's advice for teachers is to try the teacher trying to provide a method in delivering material that makes students vibrant for example giving material through video so that students don't feel bored.

Keywords: Representation Ability, Statistics.
\end{abstract}




\section{Pendahuluan}

Pendidikan merupakan suatu kebutuhan yang sangat penting bagi kelangsungan hidup manusia, juga bagi perkembangan dan kemajuan suatu bangsa (Rafid, 2018; Asdar, Arwadi, \& Rismayanti, 2021). Agar tujuan pendidikan bisa tercapai dengan seoptimal mungkin, maka guru sebagai pendidik perlu untuk dapat mengembangkan proses pembelajaran sesuai dengan kondisi dan zaman sekarang (Zein, 2016; Afriansyah, dkk., 2020). Peningkatan mutu pendidikan berarti pula peningkatan sumber daya manusia, oleh karena itu diperlukan suatu proses pembelajaran di antaranya adalah pembelajaran dalam bidang matematika. Salah satu materi pelajaran dalam matematika adalah statistika (Maya \& Setiawan, 2018; Permatasari \& Nuraeni, 2021). Statistika sangat dibutuhkan bagi perkembangan dan kemajuan suatu bangsa (Timotius, 2017; Nugraha \& Basuki, 2021). Menurut Dewi, Khodijah, dan Zanthy (2020) bahwa salah satu yang membuat suatu negara menjadi berhasil dan maju adalah ilmu statistika. Sehingga, materi statistika perlu mendapat perhatian dalam pembelajaran matematika di sekolah.

Tujuan pembelajaran matematika disetiap jenjang pendidikan diantaranya untuk mengembangkan kemampuan matematis peserta didik. Pengembangan kemampuan ini sangat diperlukan agar siswa lebih memahami konsep yang dipelajari dan dapat menerapkannya dalam berbagai situasi (Fitri \& Munzir, 2017; Masfufah \& Afriansyah, 2021). Tujuan pembelajaran matematika (Permendiknas No 22 tahun 2016) berdasarkan kurikulum tingkat satuan pendidikan (KTSP) adalah agar peserta didik memiliki kemampuan sebagai berikut:

1. Memahami konsep matematika menjelaskan keterkaitan atar konsep dan mengaplikasikan konsep atau algoritma, secara luwes, akurat, efisien, dan tepat dalam pemecahan masalah.

2. Menggunakan penalaran pada pola dan sifat, melakukan manipulasi matematika dalam membuat generalisasi, menyusun bukti atau menjelaskan gagasan, dan pernyataan matematika.

3. Memecahkan masalah yang meliputi kemampuan masalah, merancang model matematika, menyelesaikan model, dan menafsirkan solusi yang diperoleh.

4. Mengkomunikasikan gagasan dengan simbol, tabel, diagram atau media lain untuk memperjelas keadaan masalah.

5. Memiliki sikap menghargai kegunaan matematika dalam kehidupan yaitu memiliki rasa ingin tahu,perhatian, dan minat dalam memperlajari matematika, serta sikap ulet dan percaya diri dalam pemecahan masalah.

Dari uraian diatas pada poin ketiga dan keempat, terlihat bahwa beberapa kemampuan yang harus dimiliki yaitu kemampuan dalam menampilkan sesuatu berupa simbol, tabel, diagram atau media lain yang semuanya itu bertujuan untuk memperjelas masalah dan pada akhirnya digunakan untuk merancang model dalam pemecahan masalah dalam matematika. Dalam hal ini, salah satu kemampuan matematis yang mencakup beberapa aspek tersebut adalah kemampuan representasi matematis. Kemampuan representasi sangat penting, karena digunakan sebagai dasar dalam pembelajaran matematika 
(Sabirin, 2014; Wijaya, 2018; Suningsih \& Istiani, 2021)

Menurut Fitri \& Munzir (2017) Representasi matematis merupakan suatu ungkapan dari ide dan gagasan siswa dalam menyelesaikan permasalahan matematika. Representasi berperan dalam membantu peningkatan pemahaman siswa terhadap konsep matematika (Damayanti \& Afriansyah, 2018; Rochmad \& Wardono, 2019; Maryati \& Monica, 2021). Kemampuan representasi siswa dapat memberikan informasi kepada guru mengenai bagaimana siswa berpikir mengenai suatu konteks atau ide matematika, tentang pola dan kecenderungan siswa dalam memahami suatu konsep (Puspandari, Praja, \& Muhtarulloh, 2019; Agustina \& Sumartini, 2021). Oleh karena itu, guru perlu mencari cara yang tepat untuk meningkatkan kemampuan representasi siswa dalam pembelajaran matematika. Representasi dapat mengembangkan, memperdalam pemahaman siswa akan konsep dan hubungan antar konsep matematika yang telah mereka miliki melalui membuat, membandingkan dan menggunakan representasi (Annajmi \& Afri, 2019; Aisyah \& Madio, 2021).

Meskipun kemampuan representasi matematis sangat penting dalam pembelajaran matematika, akan tetapi dalam kenyataannya siswa cenderung meniru langkah guru dalam menyelesaikan masalah (Maulydia, 2017; Inayah, 2018; Yenni \& Sukmawati, 2020). Akibatnya kemampuan representasi siswa tidak berkembang, padahal representasi matematis sangat diperlukan dalam pembelajaran matematika baik bagi siswa ataupun bagi guru (Hutagaol, 2013; Muhamad, 2017; Yusriyah \& Noordyana, 2021). Mungkin ini disebabkan oleh keterbatasan pengetahuan guru tentang representasi matematis dan peranannya dalam pembelajaran matematika (Gaffar, Afriadi, \& Satriani, 2019; Suwanti \& Maryati, 2021).

Penelitian yang dilakukan oleh Sri Wahyuningsih (Ratna, 2019) menunjukkan bahwa kemampuan representasi yang ia teliti masih rendah. Hal ini disebabkan oleh beberapa faktor, diantaranya adalah kurangnya motivasi siswa dalam mendengarkan dan membaca soal yang diberikan, kurangnya kemandirian siswa dalam belajar dengan cara bekerja sama dengan siswa lain, kurangnya keberanian siswa untuk mempresentasikan jawaban yang mereka peroleh.

Triono (2017) dalam penelitiannya menyatakan bahwa Kemampuan representasi matematis siswa dalam bentuk gambar terlihat banyak siswa belum mampu mengubah simbol matematis kedalam bentuk gambar, untuk kemampuan representasi simbol, sebagian siswa terlihat sudah mampu menggunakan representatif simbol, kesalahan siswa pada umumnya terlihat pada saat mengubah permasalahan ke dalam model matematika dan untuk kemampuan representasi verbal sebagian siswa sudah mampu menggunakan representasi verbal meskipun beberapa diantaranya masih belum bisa menyampaikan ide matematisnya dengan bahasanya sendiri. Hutagaol (2013) menyatakan bahwa Permasalahan pembelajaran matematika 
yaitu kurang berkembangnya kemampuan representasi siswa, karena siswa tidak diberi kesempatan untuk menghadirkan representasinya sendiri tetapi harus mengikuti apa yang sudah dicontohkan oleh gurunya. Oleh sebab itu sebelum melaksanakan pembelajaran hendaknya guru merencanakan model yang sesuai untuk diterapkan pada materi yang akan diajarkan. Berdasarkan konteks penelitian yang telah disampaikan tersebut, peneliti tertarik untuk melakukan penelitian dengan judul: Analisis Kemampuan Representasi Matematis Siswa SMP Pada Materi Statistika.

\section{Metode}

Pendekatan yang digunakan dalam penelitian ini adalah pendekatan kualitatif yaitu suatu prosedur penelitian yang menghasilkan data deskriptif berupa ucapan atau tulisan dan perilaku yang dapat diamati dari subyek itu sendiri (Indriyana, 2020).

Menurut Shidiq \& Choiri (2019) penelitian kualitatif adalah penelitian yang menghasilkan penemuan-penemuan yang tidak dapat dicapai dengan menggunakan prosedur statistika atau dengan cara kuantitatif.

Dalam pendekatan kualitatif, peneliti memperoleh data yang mendalam sehingga dapat mengetahui kemampuan representasi matematis siswa SMP pada materi statistika kelas VIII.

Jenis penelitian yang digunakan dalam penelitian ini adalah penelitian deskriptif. Menurut Adabiah (2018) penelitian deskriptif merupakan penelitian yang menghasilkan data deskriptif berupa kata- kata tertulis atau lisan dari responden atau prilaku yang diamati.

Analisis data merupakan rangkaian kegiatan penelaahan, pengelompokan, sistematisasi, penafsiran dan verifikasi data agar sebuah fenomena memiliki nilai sosial, akademis dan ilmiah (Pane, El Fikri, \& Siregar, 2020). Analisis data ini dilakukan setelah data yang diperoleh dari sampel melalui instrumen yang dipilih dan akan digunakan untuk menjawab masalah dalam penelitian atau untuk menguji hipotesis yang diajukan melalui penyajian data.

Lokasi penelitian ini dilaksanakan di Kampung Cikadu, Desa Tanjungsari, Kecamatan Salawu, Kabupaten Tasikmalaya. Subjek yang diteliti adalah siswa kelas VIII Di SMPN 2 Salawu yang terdiri dari 3 orang subjek yang diteliti. Teknik pengumpulan data dalam penelitian ini menggunakan metode tes tertulis, wawancara dan dokumentasi. Teknik analisa data dalam penelitian ini yaitu pengumpulan data, reduksi data, menyajikan data, dan penarikan kesimpulan.

\section{Hasil dan Pembahasan}

\section{A. Kemampuan Representasi Verbal}

Siswa diperintahkan untuk mengerjakan soal, dimana soal tersebut mengharuskan siswa untuk menuliskan langkah-langkah pengerjaan soal dengan menggunakan kata-kata atau teks tertulis dalam materi statistika, soal ini berkaitan dengan ukuran pemusatan data dan ukuran penyebaran data. Tujuan dari soal ini untuk menganalisa kemampuan representasi siswa dalam materi statistika.

Dari hasil analisis yang dilakukan oleh peneliti, diperoleh hasil bahwa kemampuan 
representasi matematis siswa pada indikator kemampuan representasi verbal, dari ketiga subjek yang diteliti rata-rata cukup menguasai kemampuan representasi verbal. Akan tetapi pada jawaban tes tulis, ketiga subjek yang diteliti tidak menguraikan langkah-langkahnya dan hanya terfokus pada hasil akhir. Dari pengalaman penulis dalam mengajar fakta ini sering ditemukan pada banyak siswa. Sangat jarang siswa terampil bersamaan dalam mempresentasikan secara verbal dan tertulis. Sesuai dengan yang dikatakan Anwar (2018) bahwa fakta ini dapat dijadikan dasar agar kita bisa meneliti lebih lanjut tentang metode pembelajaran statistika yang mampu melatih siswa agar kemampuan representasi secara verbal maupun tertulis dalam kategori tinggi.

\section{B. Kemampuan Representasi Visual}

Siswa diperintahkan untuk membuat gambar diagram dari suatu permasalahan dan menyajikan data dalam bentuk prediksi atau tabel, dimana soal tersebut berkaitan dengan materi ukuran penyebaran data dan ukuran pemusatan data. Soal ini ditujukan untuk menganalisa kemampuan siswa dalam representasi gambar. Apakah siswa mengerti arti dari gambar yang disuguhkan akan tercermin dalam jawaban soal ini.

Dari hasil analisis yang dilakukan oleh peneliti, diperoleh hasil bahwa kemampuan representasi matematis siswa pada indikator representasi gambar atau visual, ketiga subjek yang diteliti rata-rata cukup memahami representasi gambar atau visual akan tetapi ketiga subjek yang diteliti kurang memahami penyesuaian angka pada pembuatan grafik. Temuan fakta ini bisa menjadi ide penelitian selanjutnya bagaimana cara memahamkan pembuatan grafik kepada para siswa. Bagaimana memahamkan siswa dari gambar ke representasi verbal dan tertulis ataupun sebaliknya. Pada tema statistik melakukan pembelajaran dengan tujuan tersebut bukan hal mudah. Ditambah tantangan guru untuk membuat pembelajaran menyenangkan dan bermakna. Hal ini sejalan dengan penelitian Nurdin dkk. (2019) bahwa fakta yang ditemukan ini bisa melatarbelakangi suatu penelitian lanjutan tentang metode yang menyenangkan dan efektif untuk meningkatkan kemampuan representasi visual siswa dalam mata pelajaran statistika.

\section{Kemampuan Representasi Simbol}

Siswa diperintahkan untuk menentukan harga satuan dari jam tangan dan membuat persamaan atau model matematis dari representasi lain yang diberikan dan penyelesaian masalah dalam materi statistika mengenai ukuran pemusatan data.

Dari hasil analisis yang dilakukan oleh peneliti, diperoleh hasil bahwa kemampuan representasi matematis siswa pada indikator representasi simbol, sebagian subjek yang diteliti sudah memahami kemampuan representasi simbol, akan tetapi ada salah satu subjek yang diteliti kurang memahami representasi simbol dengan tidak mencantumkan model matematikanya dan tidak menentukan harga dari satuan jam tangan. Dalam hal ini sesuai dengan penelitian Amir (2014) bahwa pembelajaran matematika secara 
umum sangat penting adanya penekanan kepada siswa tentang pentingnya simbol dan pentingnya mereka memperhatikan dan menggunakan simbol matematika dengan benar.

\section{Pemahaman Materi Statistika}

Dari hasil analisis yang dilakukan oleh peneliti, diperoleh hasil bahwa pemahaman subjek yang diteliti pada materi statistika sudah cukup baik. Ketiga subjek yang diteliti mengerjakan semua soal yang diberikan, dimana soal pertama dan kedua siswa diperintahkan untuk menuliskan langkah-langkah pengerjaan soal dengan menggunakan kata-kata atau teks tertulis dalam materi statistika, soal ini berkaitan dengan ukuran pemusatan data dan ukuran penyebaran data. Dilihat dari jawaban rata-rata subjek yang diteliti bisa mengerjakan, akan tetapi ada beberapa jawaban pada tiap soal yang menuliskan jawaban kurang lengkap tidak sesuai dengan arahan soal. Dari soal nomor tiga dan empat, diperintahkan untuk membuat grafik dan menyajikan data dalam bentuk tabel. Dilihat dari jawaban yang diberikan oleh ketiga subjek, rata-rata subjek yang diteliti sudah cukup memahami baik dalam pembuatan diagram maupun penyajian data dalam bentuk tabel. Akan tetapi ketiga subjek yang diteliti kurang memahami cara menentukan penyesuaian angka dalam pembuatan grafik. Sedangkan dari soal nomor lima, subjek yang diteliti diperintahkan untuk membuat persamaan atau model matematis dari representasi lain yang diberikan dimana soal ini berkaitan dengan ukuran pemusatan data. Dilihat dari jawaban yang diberikan oleh ketiga subjek yang diteliti, dua subjek menjawab dengan benar akan tetapi ada satu subjek yang arah jawabannya sudah benar tetapi tidak menyelesaikan jawabannya dimana subjek tersebut tidak membuat model matematis dan tidak menentukan harga dari satuan jam tangan, hal ini bersesuaian dengan penelitian Liyana \& Ferdianto (2018).

\section{Penutup}

Berdasarkan hasil penelitian dan pembahasan pada penelitian ini, maka penulis menarik simpulan dari hasil tes tulis dan wawancara dari 3 orang subjek yang diteliti sebagai berikut:

1. Indikator pertama dari kemampuan representasi matematis yaitu kemampuan representasi verbal, konsep cukup dikuasai oleh ketiga subjek yang diteliti tetapi pada jawaban tes tulis, ketiga subjek yang diteliti tidak menguraikan langkah-langkahnya dan hanya terfokus pada hasil akhir.

2. Indikator kedua dari kemampuan representasi matematis yaitu kemampuan representasi gambar atau visual, konsep cukup dikuasai ketiga subjek yang diteliti tetapi ketiga subjek yang diteliti kurang memahami penyesuaian angka pada pembuatan grafik.

3. Indikator ketiga dari kemampuan representasi matematis yaitu kemampuan representasi simbol, hanya dikuasai oleh dua subjek yang diteliti. Sedangkan satu subjek tidak menguasai indikator tersebut hal ini disebabkan karena siswa tersebut tidak memahami konsep materi yang terdapat pada soal dengan indikator kemampuan representasi simbol. 
4. Pemahaman ketiga subjek yang diteliti pada materi statistika rata-rata sudah cukup memahami. Semua subjek mengerjakan seluruh soal yang diberikan, akan tetapi ada beberapa jawaban dari tiap soal yang tidak dikerjakan sampai selesai, tidak menuliskan langkah-langkah dalam katakata, hal ini mungkin dikarenakan subjek terlalu tergesa-gesa dalam mengerjakan dan tidak memahami soal dengan benar. Dalam tulisan ini penulis memberikan saran supaya dalam penelitian selanjutnya dapat dikaji tentang metode mengajar statistika yang menyenangkan dan efektif dalam melatih kemampuan representasi siswa secara verbal maupun tertulis. Dapat juga penelitian di bidang pendidikan statistika untuk tujuan melatih kemampuan lainnya seperti kemampuan prosedural dalam bermatematika siswa. Statistika banyak memiliki tema yang dapat digunakan untuk melatih kemampuan prosedural bermatematika, kemampuan ini penting juga dimiliki para siswa.

\section{DAfTAR Pustaka}

Adabiah, R. (2018). Analisis kemampuan representasi matematis siswa dalam menyelesaikan soal segi empat di MTs. Nw dasan tapen gerung lombok barat.

Afriansyah, E. A., Sofyan, D., Puspitasasri, N., Lurytawati, I. P., Sundayana, R., Maryati, I., \& Basuki, B. (2020). Edmodo E-learning Media Training for Learning Optimization. Journal Pekemas, 3(2), 3339.

Agustina, T. B., \& Sumartini, T. S. (2021). Kemampuan Representasi Matematis Siswa Melalui Model STAD dan
TPS. Plusminus: Jurnal Pendidikan Matematika, 1(2), 315-326.

Aisyah, A. S. N., \& Madio, S. S. (2021). Peningkatan Kemampuan Representasi Matematis Siswa dengan Pembelajaran Berbasis Masalah Melalui Pendekatan Konstekstual dan Matematika Realistik. Plusminus: Jurnal Pendidikan Matematika, 1(2), 363-372.

Amir, A. (2014). Pembelajaran matematika SD dengan menggunakan media manipulatif. In Forum Paedagogik (Vol. 6, No. 01).

Annajmi, A., \& Afri, L. E. (2019). Pengaruh Penggunaan Lembar Aktivitas Siswa Berbasis Metode Penemuan Terbimbing terhadap Peningkatan Kemampuan Representasi Matematis Siswa. Mosharafa: Jurnal Pendidikan Matematika, 8(1), 95-106.

Anwar, M. (2018). Menjadi guru profesional. Prenada Media.

Asdar, A., Arwadi, F., \& Rismayanti, R. (2021). Pendekatan Pendidikan Matematika Realistik terhadap Hasil Belajar Matematika dan Self Confidence Siswa SMP. Plusminus: Jurnal Pendidikan Matematika, 1(1), 1-16.

Damayanti, R., \& Afriansyah, E. A. (2018). Perbandingan Kemampuan Representasi Matematis Siswa antara Contextual Teaching and Learning dan Problem Based Learning. JIPM (Jurnal IImiah Pendidikan Matematika), 7(1), 30-39.

Dewi, D. K., Khodijah, S. S., \& Zanthy, L. S. (2020). Analisis kesulitan matematik siswa smp pada materi statistika, 4(1), 1-7.

Fitri, N., Munzir S., \& M. D. (2017). Meningkatkan Kemampuan Representasi Matematis Melalui 
Penerapan Model Problem Based Learning. Jurnal Didaktik Matematika, 4(1), 59-67. https://doi.org/10.24815/jdm.v4i1.6902 Gaffar, A., Afriadi, A., \& Satriani, S. (2019). Analisis Kemampuan Representasi Matematis Siswa dalam Menyelesaikan Soal Matematika Materi Komposisi Fungsi dan Invers Kelas XI IPA SMAN 1 Gowa. Pedagogy: Jurnal Pendidikan Matematika, 4(1), 42-52.

Hutagaol, K. (2013). Pembelajaran Kontekstual Untuk Meningkatkan Kemampuan Representasi Matematis Siswa Sekolah Menengah Pertama. Infinity Journal, 2(1), 85-99. https://doi.org/10.22460/infinity.v2i1.27 Inayah, S. (2018). Penerapan Pembelajaran Kuantum Untuk Meningkatkan Kemampuan Pemecahan Masalah Dan Representasi Multipel Matematis Siswa. KALAMATIKA Jurnal Pendidikan Matematika, 3(1), 1-16.

Indriyani, E. (2020). Strategi Pemasaran Obat Pertanian untuk Penjualan Produk di Toko Pertanian Elin Jombang (Doctoral dissertation, STIE Mahardhika Surabaya).

Liyana, D., \& Ferdianto, F. (2018). Analisis kemampuan pemecahan masalah siswa kelas XII SMA materi program linear. Gammath: Jurnal IImiah Program Studi Pendidikan Matematika, 3(2), 8287.

Maryati, I., \& Monica, V. (2021). Pembelajaran Berbasis Masalah dan Inkuiri dalam Kemampuan Representasi Matematis. Mosharafa: Jurnal Pendidikan Matematika, 10(2), 333-344. Masfufah, R., \& Afriansyah, E. A. (2021). Analisis Kemampuan Literasi Matematis
Siswa melalui Soal PISA. Mosharafa: Jurnal Pendidikan Matematika, 10(2), 291-300.

Maulydia, S. S. (2017). Hubungan Antara Kemampuan Representasi Matematis Dengan Kepercayaan Diri, Kemandirian Belajar, Motivasi Belajar, Disposisi Matematis Dan Gender Siswa SMK (Doctoral dissertation, UNIMED).

Maya, R., \& Setiawan, W. (2018). Analisis kemampuan komunikasi matematis siswa smp pada materi statistika. JPMI (Jurnal Pembelajaran Matematika Inovatif), 1(6), 1095-1104.

Muhamad, N. (2017). Pengaruh metode discovery learning untuk meningkatkan representasi matematis dan percaya diri siswa. Jurnal Pendidikan UNIGA, 10(1), 9-22.

Nugraha, M. R., \& Basuki, B. (2021). Kesulitan Kemampuan Pemecahan Masalah Matematis Siswa SMP di Desa Mulyasari pada Materi Statistika. Plusminus: Jurnal Pendidikan Matematika, 1(2), 235-248.

Nurdin, E., Ma'aruf, A., Amir, Z., Risnawati, R., Noviarni, N., \& Azmi, M. P. (2019). Pemanfaatan video pembelajaran berbasis Geogebra untuk meningkatkan kemampuan pemahaman konsep matematis siswa SMK.Jurnal Riset Pendidikan Matematika, 6(1), 87-98.

Pane, D. N., El Fikri, M., \& Siregar, N. (2020). Upaya Peningkatan Repurchase Intention Melalui Sosial Media dan Word of Mouth terhadap Hotel Parbaba Beach di Daerah Pariwisata Kabupaten Samosir. JUMANT, 12(1), 12-20.

Permatasari, R., \& Nuraeni, R. (2021). Kesulitan Belajar Siswa SMP mengenai Kemampuan Koneksi Matematis pada 
Materi Statistika. Plusminus: Jurnal Pendidikan Matematika, 1(1), 145-156.

Puspandari, I., Praja, E. S., \& Muhtarulloh, F. (2019). Pengembangan bahan ajar dengan pendekatan induktif untuk meningkatkan kemampuan representasi matematis siswa SMP.Mosharafa: Jurnal Pendidikan Matematika, 8(2), 307-318.

Rafid, R. (2018). Konsep Kepribadian Muslim Muhammad Iqbal Perspektif Pendidikan Islam sebagai Upaya Pengembangan dan Penguatan Karakter Generasi Milenial. E-Jurnal Mitra Pendidikan, 2(7), 711-718.

Rahman, A. A. (2018). Strategi Belajar Mengajar Matematika. In Firdaus Nuzula\&Cut Eva Nasryah (Ed.), buku (1st ed.). Syiah Kuala University Press Perpustakaan.

https://doi.org/10.1017/CBO978110741 5324.004

Ranisa, J. (2016). Kemampuan Representasi

Dan Komunikasi Matematis Peserta Didik SMA Ditinjau Dari Prestasi Belajar Dan Gaya Kognitif. PYTHAGORAS: Jurnal Pendidikan Matematika, 11(2), 193206.

https://doi.org/10.21831/pg.v11i2.1065 5

Sabirin, M. (2014). Representasi dalam Pembelajaran Matematika. Jurnal Pendidikan Matematika, 1(2), 33-44. https://doi.org/10.18592/jpm.v1i2.49

Sari. (2019). Analisis Representasi Matematis Siswa SMA Melalui Model Pembelajaran Problem Based Learning Materi Fungsi Trigonometri. Jurnal LEMMA, 5(2), 148-156. https://doi.org/10.22202/jl.2019.v5i2.33 73.

Shidiq, U., \& Choiri, M. (2019). Metode Penelitian Kualitatif di Bidang Pendidikan. In D. A. M. A. Mujahidin (Ed.), Journal of Chemical Information and Modeling, 53(9). https://doi.org/10.1017/CB0978110741 5324.004

Sugiyono (2013). Metode Penelitian Pendidikan Pendekatan Kualitatif, Kuantitatif, dan R\&D. Alfabeta: Bandung.

Suningsih, A., \& Istiani, A. (2021). Analisis Kemampuan Representasi Matematis Siswa. Mosharafa: Jurnal Pendidikan Matematika, 10(2), 225-234.

Suwanti, S., \& Maryati, I. (2021). Kemampuan Representasi Matematis Siswa Melalui Model Problem Based Learning dan Probing Prompting Learning. Plusminus: Jurnal Pendidikan Matematika, 1(2), 303-314.

Timotius, K. H. (2017). Pengantar Metodologi Penelitian: Pendekatan Manajemen Pengetahuan untuk Perkembangan Pengetahuan. Penerbit Andi.

Triono, A. (2017). Analisis kemampuan representasi matematis siswa kelas viii smp negeri 3 tangerang selatan. 1-121.

Ulya, M. R., Rochmad, \& Wardono. (2019). Efektivitas Pembelajaran Flipped Classroom dengan Pendekatan Matematika Realistik Indonesia terhadap Kemampuan Representasi Ditinjau dari Self-Efficacy. Jurnal PRISMA, 2, 116-123.

Wijaya, C. B. (2018). Analisis Kemampuan Representasi Matematis Siswa Dalam 
Menyelesaikan Soal Lingkaran Pada

Kelas VII-B Mts Assyafi ' iyah Gondang, 4(2), 115-124.

Yenni, Y., \& Sukmawati, R. (2020). Analisis

Kemampuan Representasi Matematis

Mahasiswa Berdasarkan Motivasi

Belajar. Mosharafa: Jurnal Pendidikan

Matematika, 9(2), 251-262.

Yuniza, C. (2018). Summary for

Policymakers. Journal of Chemical

Information and Modeling, 1(2), 93-

104.

https://doi.org/10.1017/CBO97811074

15324.004

Yusriyah, Y., \& Noordyana, M. A. (2021).

Kemampuan Representasi Matematis

Siswa SMP pada Materi Penyajian Data

di Desa Bungbulang. Plusminus: Jurnal

Pendidikan Matematika, 1(1), 47-60.

Zein, M. (2016). Peran guru dalam pengembangan pembelajaran. Jurnal Inspiratif Pendidikan, 5(2), 274-285.

\section{Riwayat Hidup Penulis}

\section{Endah Silviani, S.Pd.}

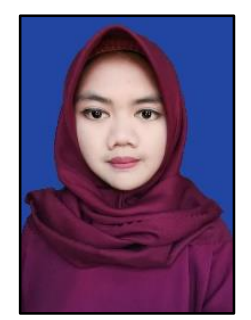

Lahir di Garut, 16 Februari Tahun 1998. Lulus dari Institut Pendidikan Indonesia (IPI) Garut Tahun 2020 dengan Program Studi Pendidikan Matematika.

\section{Dian Mardiani, M.PMat.}

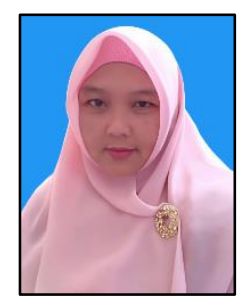

Lahir di Garut, 30 Oktober Tahun 1978. Dosen tetap di Institut Pendidikan Indonesia (IPI) Garut. Studi S1 (bidang Pendidikan Matematika) di Universitas Yogyakarta, lulus tahun 2002. Studi S2 (bidang Pengajaran Matematika) di Institut Teknologi Bandung, lulus tahun 2011.

\section{Deddy Sofyan, M.Pd.}

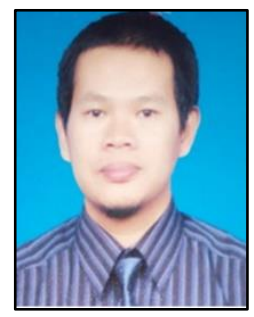

Lahir di Bandung, 28 Oktober Tahun 1968. Dosen tetap di Institut Pendidikan Indonesia (IPI) Garut. Studi S1 (bidang Pendidikan Matematika) di IKIP Bandund, lulus tahun 1992. Studi S2 (bidang Pendidikan Matematika) di UPI, lulus tahun 2008. 